\title{
Non-Coding RNAs to Aid in Neurological Prognosis after Cardiac Arrest
}

\author{
Antonio Salgado-Somoza ${ }^{1,+}$, Francesca Maria Stefanizzi ${ }^{1,+}+$ , Pascal Stammet ${ }^{2,+}$, \\ David Erlinge ${ }^{3,+}$, Hans Friberg ${ }^{4,+}$, Niklas Nielsen ${ }^{5,+}$ and Yvan Devaux $1,+, * \mathbb{D}$ \\ 1 Cardiovascular Research Unit, Department of Population Health, Luxembourg Institute of Health, L-1445 \\ Strassen, Luxembourg; antonio.salgadosomoza@lih.lu (A.S.-S.); francescamaria.stefanizzi@lih.lu (F.M.S.) \\ 2 Medical and Health Department, Luxembourg Fire and Rescue Corps, L-2557 Luxembourg, Luxembourg; \\ Pascal.Stammet@secours.etat.lu \\ 3 Department of Cardiology, Clinical Sciences, Lund University, 22185 Lund, Sweden; \\ david.erlinge@gmail.com \\ 4 Skane University Hospital, Lund University, 22185 Malmo, Sweden; hans.a.friberg@gmail.com \\ 5 Helsingborg Hospital, Lund University, 25187 Helsingborg, Sweden; niklas.nielsen@telia.com \\ * Correspondence: yvan.devaux@lih.lu; Tel.: +352-26970-300 \\ + On behalf of the Cardiolinc ${ }^{\mathrm{TM}}$ network.
}

Received: 8 November 2018; Accepted: 12 December 2018; Published: 18 December 2018

\begin{abstract}
Cardiovascular disease in general, and sudden cardiac death in particular, have an enormous socio-economic burden worldwide. Despite significant efforts to improve cardiopulmonary resuscitation, survival rates remain low. Moreover, patients who survive to hospital discharge have a high risk of developing severe physical or neurological symptoms. Being able to predict outcomes after resuscitation from cardiac arrest would make it possible to tailor healthcare approaches, thereby maximising efforts for those who would mostly benefit from aggressive therapy. However, the identification of patients at risk of poor recovery after cardiac arrest is still a challenging task which could be facilitated by novel biomarkers. Recent investigations have recognised the potential of non-coding RNAs to aid in outcome prediction after cardiac arrest. In this review, we summarize recent discoveries and propose a handful of novel perspectives for the use of non-coding RNAs to predict outcome after cardiac arrest, discussing their use for precision medicine.
\end{abstract}

Keywords: cardiac arrest; biomarkers; non-coding RNAs

\section{Background}

Despite joint efforts from the clinical and research communities in the field, cardiovascular disease remains the leading cause of mortality in the modern world, accounting for $45 \%$ of all deaths in Europe [1]. A high percentage of these deaths is attributed to sudden death or cardiac arrest (CA). According to the Declaration of the European Parliament of 14 June 2012, some 400,000 people suffer a sudden out-of-hospital CA each year in Europe. Similar numbers can be found in the United States, where cardiac arrest affects more than 350,000 people per year [2].

\section{Outcome after Cardiac Arrest}

Outcome is extremely poor following CA, as more than half of the people who suffer an arrest will die before reaching the hospital. Overall, less than $10 \%$ of patients who receive cardiopulmonary resuscitation survive after out-of-hospital CA (Figure 1). The survival rate slightly ameliorates when CA occurs inside the hospital [3,4]. The expectancy of survival depends on both extrinsic (management shortly after the event or in the hospital) and intrinsic factors (gender, age ... ). 
₹400.000 OHCA PER YEAR IN EUROPE

>350.000 OHCA PER YEAR IN THE UNITED STATES

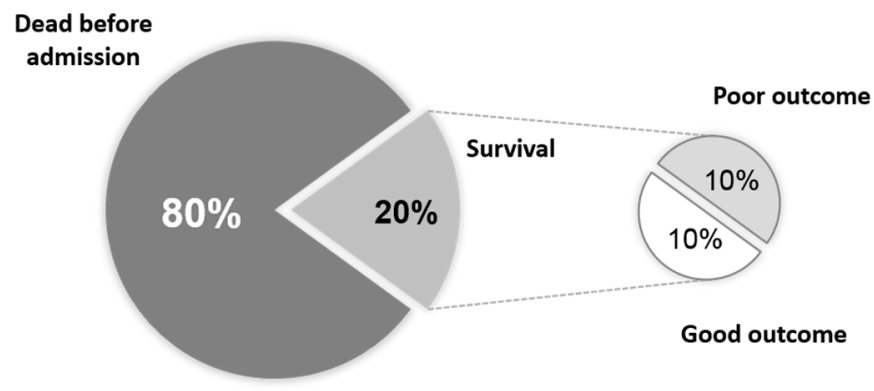

Figure 1. Graphic representation of the patient survival (showed as percentage) after Out-of-Hospital Cardiac Arrest (OHCA).

An important variable affecting the outcome after out-of-hospital CA (OHCA) is the application of proper and rapid cardiopulmonary resuscitation by bystanders [5,6]. The improvement of cardiopulmonary resuscitation techniques and the increased presence of automated external defibrillators in public areas are at least partly responsible for the tendency towards the better outcomes and survival rates observed in the past decades $[4,7,8]$. In addition, targeted temperature management at $33-36{ }^{\circ} \mathrm{C}$ has been implemented in clinical practice to protect the brain from ischemia-induced injury, but many questions about the ideal target temperature management remain unsolved [9]. As such, there is a need for new strategies to improve survival after OHCA.

Among patients who reach the hospital alive, approximately $50 \%$ survive in good condition (i.e., without major neurological sequelae [10]), whilst the other half suffer severe and irreversible neurological damage often leading to death [11], despite the use of modern, invasive, and intensive care treatment including targeted temperature management. In fact, in addition to hypothermia and early coronary reperfusion, patients in critical conditions need close monitoring of several parameters such as electrolytes and blood glucose. Mechanical ventilator supports are required to avoid hyperoxia and to ensure adequate ventilation. Pharmacological hemodynamic supports and devices are also needed in case of cardiogenic shock, mainly to improve arterial pressure and renal function. Lastly, a series of specific treatments are involved in case of other organ complications.

As mentioned above, several intrinsic factors affect the outcome after CA. For example, females are more prone to a worse outcome, which may be explained by differences in arrest circumstances, comorbidities, and in-hospital management [12]. In a large registry, men had a higher survival rate and a better neurological outcome at hospital discharge than women [13]. As for other cardiovascular diseases, survival expectancy after CA might be higher in obese patients and smokers (often called obesity and smoking paradoxes) [14-16], even though these are known risk factors triggering this cardiovascular complication. The delay between cardiac arrest and return of spontaneous circulation (ROSC), as well as the subsequent extent of brain damage, are both strongly associated with a poor outcome [17].

\section{Prediction of Neurological Outcome after Cardiac Arrest}

Being able to predict the outcome after CA would represent a breakthrough towards personalized/precision medicine. Extensive and costly treatments could be maximized to patients who are likely to survive without major neurological sequelae, and long futile care could be avoided in patients with severe and irreversible brain damage. The withdrawal of life-sustaining therapies could be adjudicated for patients with a certain poor prognosis. Importantly, patient relatives, who often experience a long and painful waiting period before being reliably informed of the prognosis, could be guided at an early stage [18]. As stated in the 2010 European Resuscitation Guidelines for Resuscitation, 
"a means of predicting neurological outcome that can be applied to individual patients immediately after ROSC is required" [19].

Current guidelines to predict outcome after CA recommend the combined use of neurophysiological tests, reflecting brain function, and brain-derived biomarkers released in the bloodstream after disruption of the blood-brain-barrier induced by cerebral ischemia, and hence, reflecting the extent of brain injury [20]. Clinical examination of the patient is of paramount importance for outcome prediction. The absence of normal ocular reflexes or response to pain and the presence of myoclonus during the first days after ROSC are indicators of poor prognosis. However, these markers can be attenuated or masked by sedation, making their interpretation difficult and unreliable. The absence of pupillary light and corneal reflexes on day 3 after CA has been reported to reliably predict poor outcome, with a false positive rate of $0 \%$ [21]. However, neurophysiological tests are limited by the need for specific expertise and training.

Box 1. Main Protein biomarkers for CA prognosis: strengths and limitations.

\section{- Neuron specific enolase (NSE):}

Strengths: Recognized as prognostic biomarker for CA in the guidelines of the American Heart Association [22]. Blood levels are predictors of neurological outcome in a timeline going from $24 \mathrm{~h}$ to $72 \mathrm{~h}$ after ROSC [23-26]. Limitations: Increased levels are found in other disorders, leading to patient misclassification [27-29]. Haemolysis can increase serum levels of NSE. Outcome prediction earlier than $48 \mathrm{~h}$ shows lack of accuracy.

\section{- S100 calcium-binding protein B (S100B):}

Strengths: Predicts the ongoing of cerebral injury at a very early stage after CA [30,31]. Limitations: Lacks specificity and does not add value to the current prognostication models [26].

\section{- TAU protein:}

Strengths: High serum levels reveal axonal dysfunction. Increased circulating levels of the protein can be detected in patients after CA with a poor neurological outcome.

Limitations: Peaks of TAU are reached at $48 \mathrm{~h}$ and $96 \mathrm{~h}$ after ROSC [32,33]. Few data supporting its utility as marker of severity of acute brain injury after CA [32,33].

\section{- Plasma neurofilament light chain (NfL)}

Strengths: Sensitive marker of long-term outcome in patients after CA, its blood levels increase significantly and remain stable for 7 days after CA [34].

Limitations: Supporting evidence comes only from small single-centre patient cohorts.

\section{- Procalcitonin (PCT)}

Strengths: Its circulating levels increase significantly, within $2 \mathrm{~h}$, during bacterial infections. Various small-cohort studies showed the PCT potential to predict poor outcome in CA patients with high accuracy [35-37]. Limitations: Confirmed biomarker for detection of acute infections and sepsis, which can act as confounding factors [38]. Larger studies needed to support its potential value as biomarker.

Neuron-specific enolase (NSE), the only biomarker so far recommended in the guidelines [20], needs serial assessment and high values in order to optimally predict poor outcomes $[17,39]$. In addition, there is no consensus on the threshold to be used as a definition of a high value, with suggestions ranging between $25-85 \mathrm{mg} \mathrm{L}^{-1}$ measured at different time points among studies [18,40]. Recently, Chung-Esaki and colleagues proposed the NSE ratio, instead of its absolute value, to track the protein changes over time after CA; however no threshold value has been identified, and future studies on larger cohorts need to be performed to validate the advantages of this method [41]. $\mathrm{S100B}$ is an acidic $\mathrm{Ca}^{2+}$-binding protein predominantly expressed in astroglial cells which is detected in the blood after CA and which has been reported as a potential biomarker of outcome [42,43]. Its use is limited by fluctuating levels due to peripheral injuries and to a short half-life of $25 \mathrm{~min}$ followed by renal clearance [44,45]. Inflammatory and cardiac markers such as interleukin-6 [46], procalcitonin [47], brain natriuretic peptides [48] and troponins [49] are also associated with outcome, but they are limited in accuracy (See Box 1). Lactate levels are increased in patients with poor 
outcome [50], and secretoneurin, a small peptide with a potential role in cardiomyocyte calcium homeostasis, improved the prediction of mortality and brain injury by NSE [51]. Yet, apart from NSE, only few of these markers are applied in clinical practice to help outcome prediction.

In summary, to date, no method securely predicts outcome after CA. To be clinically useful, a prognostication method requires a very low false positive rate (5\% or lower), since it is undesirable to use a method which could predict a poor outcome in a patient who would eventually recover. Therefore, novel methods or biomarkers are needed to improve prediction of outcome after CA.

\section{Non-Coding RNAs}

Here, we focus on studies reporting potential benefits of non-coding RNA biomarkers on outcome prediction after CA (Tables 1-3). The explosion of RNA knowledge in recent years has provided the tools and opportunity to explore the potential of RNA molecules as biomarkers. Much attention has been brought to RNA molecules lacking protein-coding potential following the discovery that, although $80 \%$ of human genes are effectively transcribed into RNA molecules, only less than $2 \%$ of these molecules encode proteins [52]. These so-called non-coding RNAs are a subclass of the RNA family which contains multiple types of RNAs, classified according to their sub-cellular location, function, size and protein-coding potential.

\subsection{MicroRNAs}

MicroRNAs (miRNAs) are 20-22 nucleotides-long non-coding RNA molecules involved in gene regulation. Their role in heart development and disease as well as their biomarker potential to advance personalized medicine have been extensively studied [53]. However, the study of their role in CA is still in its infancy (Table 1). In a small proof-of-concept study including 28 patients after resuscitated $\mathrm{CA}$, circulating levels of miR-122-5p and miR-21 were elevated in patients with poor outcome and were associated with neurological outcome and survival [54]. It is noteworthy that miR-21 was elevated in a murine model of traumatic brain injury [55], and plasma levels of miR-122-5p were increased in a porcine cardiogenic shock model and attenuated by hypothermia [56]. Those observations in animal models supported the results of the human small scale study. Lately, 23 microRNAs involved in neurologic, circulatory, metabolic, or vascular processes were studied in 45 patients and 15 controls from the Cardiac Arrest Blood Study. The vast majority of them were upregulated in sudden cardiac arrest when compared with age-, sex- and race-matched controls [57]. Among them, miR-122-5p presented higher expression values in successfully resuscitated patients compared to dead ones [57]. It has to be taken into account that miR-122-5p expression levels (as well as other miRNAs) could be influenced by other pathologies. Thus, a study involving 239 patients who suffered sudden cardiac death (SCD) showed lower hepatic expression of miR-122-5p and higher expression of miR-34a-5p in patients whose SCD was related to coronary artery disease $(n=68)$ compared with those with non coronary artery disease-related SCD $(n=27)$ [58]. When patients were stratified according to the level of liver damage, miR-122-5p presented the lowest expression values in patients with necroinflammatory statohepatitis, pointing at a deficit of this miRNA in the liver if this organ is subjected to an insult [58].

In another small-scale study, circulating levels of miR-124-3p, a brain-enriched miRNA, were elevated in patients with poor outcomes compared to patients with favourable outcomes [59]. Similarly to miR-21, miR-124-3p was previously described as a biomarker for ischemic brain injury, as demonstrated in an experimental model of cerebral stroke in rats [60]. It is known that circulating miRNAs can reflect brain damage, since dying neurons release microparticles carrying miRNAs in the cerebrospinal fluid [61]. As such, miR-124-3p arises as a perfect candidate to be measured in the bloodstream because its plasma levels are elevated in a rat model with a cerebral artery occlusion despite its neuron-specific origin [62]. Indeed, some miRNAs appear to be able to cross the blood brain barrier, which is disrupted following cerebral ischemia [63], and to accumulate in the blood. 
Table 1. Current knowledge of microRNAs in cardiac arrest or related brain disease.

\begin{tabular}{|c|c|c|c|c|c|}
\hline ID & Specie & Disease & Experimental Model & Observation & Ref. \\
\hline \multirow{2}{*}{ miR-21 } & Human & OHCA & - & Elevated plasma levels in patients with poor neurological outcome & [54] \\
\hline & Rat & TBI & Fluid percussion injury & Elevated serum levels in rats with poor outcome & [55] \\
\hline miR-34a & Human & SCD & $\begin{array}{l}\text { Coronary artery and } \\
\text { non-alcoholic fatty liver disease }\end{array}$ & Higher hepatic levels in coronary artery disease-related SCD & [58] \\
\hline \multirow{4}{*}{$\operatorname{miR}-122$} & \multirow{3}{*}{ Human } & OHCA & - & Elevated serum levels in patients with poor neurological outcome & {$[54,65]$} \\
\hline & & SCA & $\begin{array}{l}\text { Ventricular tachycardia-derived } \\
\text { cardiac arrest }\end{array}$ & $\begin{array}{l}\text { Elevated in plasma from patients compared to controls. } \\
\text { Elevated in successfully resuscitated or discharged alive only } \\
\text { versus patients died in the field. }\end{array}$ & [57] \\
\hline & & SCD & $\begin{array}{l}\text { Coronary artery and } \\
\text { non-alcoholic fatty liver disease }\end{array}$ & Lower hepatic levels in coronary artery disease-related SCD & [58] \\
\hline & Pig & Cardiogenic shock & LAD artery occlusion & Elevated plasma levels after injury. Attenuation by hypothermia. & [56] \\
\hline \multirow[t]{2}{*}{$\operatorname{miR}-124$} & Human & OHCA & - & $\begin{array}{l}\text { Elevated serum and plasma levels in patients with poor } \\
\text { neurological outcome }\end{array}$ & {$[59,64]$} \\
\hline & Rat & Ischemic brain damage & MCAO & Plasma biomarker of ischemic brain damage & {$[60,62]$} \\
\hline miR-4661-3p & Mouse & Mechanical injury & Primary astrocytes & $\begin{array}{l}\text { Inhibited Tnf } \alpha \text { expression after stretch injury and interacted with } \\
\text { lncRNA Gm4419 }\end{array}$ & [66] \\
\hline Other & Human & SCA & $\begin{array}{l}\text { Ventricular tachycardia-derived } \\
\text { cardiac arrest }\end{array}$ & $\begin{array}{l}\text { Expression levels of plasmatic miRs were higher }(\mathrm{n}=17) \text { or lower } \\
(\mathrm{n}=3) \text { in CA patients compared to controls. } \\
\text { Mir-122 and miR-205 were elevated in patients successfully } \\
\text { resuscitated versus death in the field. } \\
\text { Lower levels of cardiac enriched microRNAs were observed in } \\
\text { patients discharged alive versus the ones who died in the field. }\end{array}$ & [57] \\
\hline
\end{tabular}

CA: Cardiac Arrest; LAD: left anterior descending; MCAO: middle cerebral artery occlusion; OHCA: out-of-hospital cardiac arrest; SCA: Sudden Cardiac Arrest; SCD: Sudden Cardiac Death; TBI: traumatic brain injury. 
Encouraging results from these small-scale studies motivated the testing of the association between circulating miRNAs and outcome after CA in larger cohorts. Consortium members of the Target Temperature Management (TTM) —trial (NCT01020916 [9]) investigated this association in plasma samples harvested $48 \mathrm{~h}$ after CA from almost 600 CA patients. Using small RNA sequencing on 50 patients of the TTM cohort, miRNAs associated with neurological outcome, as assessed by the cerebral performance category score, were identified [64]. A follow-up validation study in the entire cohort revealed that among miRNA candidates, miR-124-3p was the most strongly associated with outcome. Together with demographic and clinical parameters, it was able to accurately predict neurological outcome (odds ratio of 1.62 with a 95\% confidence interval of 1.13-2.32) and survival (hazard ratio of 1.63 with a $95 \%$ confidence interval of 1.37-1.93) [64]. Using the same TTM-trial cohort, miR-122-5p was able to provide an incremental predictive value to a model containing both clinical parameters and miR-124-3p, showing that combining multiple explanatory variables may increase the predictive value of miRNAs [65].

\subsection{Long Non-Coding RNAs}

Long non-coding RNAs (lncRNAs) are defined as RNA molecules longer than 200 nucleotides and lacking protein-coding potential $[67,68]$. The spreading of the use of deep RNA sequencing techniques has made possible the discovery and annotation of more than 146,000 lncRNAs in human (LNCipedia 4.1 [69]). Only a minority of these lncRNAs have known roles in pathophysiology, and even fewer have been shown to regulate cardiac development and disease [70-73]. This might be due in part to the relatively low conservation of lncRNAs between species which hinders mechanistic studies in animal models. While different mechanisms of action of lncRNAs have been proposed $[70,72,73]$, much remains to be discovered regarding their regulation and function in cardiac disease. One interesting property of lncRNAs is their ability to bind and sequester miRNAs, acting as a sponge, and thereby inhibiting the action of miRNAs on gene expression.

There are some indications pointing at the potential of lncRNAs as biomarkers of cardiovascular disease $[70,72,73]$. Since lncRNA expression profiles in blood cells have been shown to be associated with outcome after acute myocardial infarction [74], and considering that the aetiology of CA is often a prior acute myocardial infarction, it can be expected that lncRNAs may also be associated with outcome after CA (Table 2).

LncRNAs are expressed in the brain and are involved in neurological disease development [75], thereby constituting candidate targets for future research. As an example, it has been shown that downregulation of the lncRNA Meg3 after $2 \mathrm{~h}$ of occlusion of the middle cerebral artery in rats reduced the lesion volume and improved neurological outcome through the stimulation of angiogenesis mediated by the Notch signalling pathway [76]. Silencing Meg3 in a human endothelial cell line induced an activation of pro-angiogenic properties of the cells, such as cell migration, sprouting and tube formation [76]. In hypertensive rats following $1 \mathrm{~h}$ of occlusion, upregulation of FosDT modulates brain damage via an indirect modulation of downstream genes of repressor element- 1 silencing transcription factor [77]. One of the downstream pathways of this transcription factor involves nuclear factor kappa B (NFkB) which is also associated with the lncRNAs C2dat1 and Gm4419. Indeed, C2dat1 regulates calmodulin kinase to promote neuronal survival after ischemia reperfusion in mice [78], while Gm4419 contributes to NFKB activation in rat microglial cells [79]. Furthermore, Gm4419 expression levels are upregulated in injured mouse astrocytes, and scavenge miR-4661-3p, which induces tumour necrosis factor alpha (TNF $\alpha$ ) production and apoptosis [66]. The later study revealed an interaction of three different members of the RNA family (one lncRNA, one miRNA and one lncRNA), which shows the complex regulation networks taking place in the affected brain. 
Table 2. Current knowledge of lncRNAs in CA-related brain disease models.

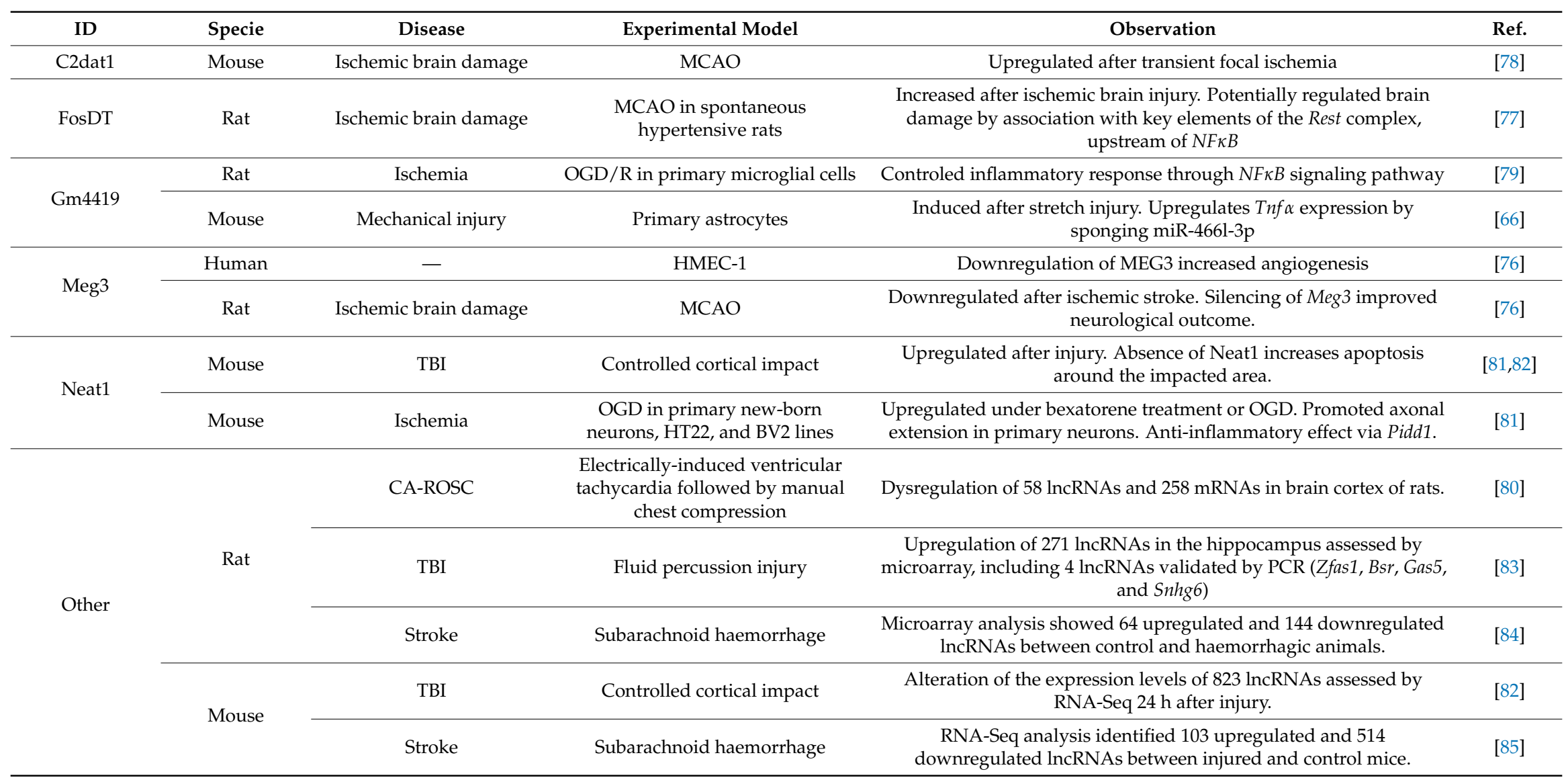

BV2: microglial cell line. CA-ROSC: Cardiac Arrest-Return to Spontaneous Circulation; HMEC-1: human microvascular endothelial cells; HT22: hippocampal neuron line MCAO: middle cerebral artery occlusion; OGD/R: oxygen and glucose deprivation/reoxygenation; PCR: Polymerase Chain Reaction; TBI: traumatic brain injury. 
Maybe the best indication about the regulation of lncRNAs after CA arose from a rat model, where ventricular fibrillation was induced by alternating current. This study showed the upregulation of 37 lncRNAs and the downregulation of 21 lncRNAs in post-CA brain samples. [80]. Results from another study showed an upregulation of the lncRNA Neat1 after treatment with bexarotene (an agonist of the retinoid $\mathrm{X}$ receptor used in some types of cancer), thereby reducing inflammation and apoptosis [81]. This observation suggested that lncRNAs may be involved in a patient's response to treatment. However, the study was carried out in different cellular and animal models whose relevance for humans needs further exploration. In addition, other attempts using animal models aimed to reflect how brain damage can alter the transcription of lncRNAs. In traumatic brain injury models in rodents, several lncRNAs, including the well-known Neat1 and Malat1, were regulated and considered as potential players in brain injury $[82,83]$. In a subarachnoid haemorrhage murine model, microarrays and deep RNA sequencing allowed researchers to identify more than 200 and 600 differentially-expressed lncRNAs, respectively [84,85]. Confirmation by PCR was achieved for several IncRNAs which were found to be either upregulated (MRuc008hvl and BC0092207) or downregulated after haemorrhage (XR_006756, MRAK017168, and MRAK038897) [84]. However, there is a lack of mechanistic studies following the discovery of the dysregulated RNAs by high throughput analysis. So, whether these lncRNAs actively contribute to brain injury or are mere bystanders remains to be determined.

In order to become useful biomarkers, IncRNAs would need to be measurable in the blood. As previously mentioned for miRNAs, the accumulation of lncRNAs in the blood will rely on their ability to cross the blood brain barrier. Whether IncRNAs have this capacity remains to be demonstrated.

\subsection{Circular RNAs}

A subclass of lncRNAs called circular RNAs (circRNAs), which are formed by a back-splicing event, showed a higher stability in body fluids compared to their linear counterparts $[86,87]$. Indeed, this circular form protects them from degradation by exoribonucleases, thus providing them with an interesting biomarker potential [88]. Although circRNAs have been proposed as candidate biomarkers of cardiovascular disease including heart failure [87], their presence in the blood has only been shown in blood cells [89], and whether they are able to cross the blood brain barrier remains to be determined. So far, there is no study directly linking the regulation of circRNAs with the prognosis after CA (Table 3).

Again, studies performed with animal models suggest a possible involvement of circRNAs in the underlying mechanisms of brain injury, be it ischemic or traumatic. Using a mouse model of stroke induced by occlusion of the middle cerebral artery, two microarray approaches using RNAse R treated RNA identified modified circRNAs patterns in the brain. Thus, after $45 \mathrm{~min}$ of ischemia and 48h of reperfusion, 1027 circRNAs were differentially expressed (914 upregulated and 113 downregulated) [90]. Among the differentially expressed RNAs, circRNA_40001, circRNA_013120, circRNA_25329 (upregulated), and circRNA_40806 (downregulated) were confirmed by PCR. When the mice were submitted to 90 min of ischemia followed by 6, 21 or $24 \mathrm{~h}$ of reperfusion, 283 circRNAs were altered in at least one time point, and 16 of them were common to all three time-points [91]. The top three upregulated (circ_008018, circ_015350, and circ_016128) and downregulated (circ_011137, circ_001729, and circ_006696) circRNAs were confirmed by PCR [91].

A microarray analysis revealed 98 upregulated and 94 downregulated circRNAs in a traumatic brain injury model [92], where four of them were confirmed by PCR (circ_006508 and circ_010705 were up-regulated whilst circ_001167 and circ_001168 were down-regulated). CircRNA dysregulation was studied in exosomes from brain explants of mouse with traumatic brain injury [93]. Next generation sequencing followed by a specific bioinformatics pipeline for the analysis of circRNAs identified 155 up- and 76 down-regulated circRNAs [93]. Therefore, the circular RNA reservoir might constitute another source of interesting biomarkers of outcome after CA. 
Table 3. Current knowledge of circRNAs in brain disease animal models.

\begin{tabular}{ccccc}
\hline Specie & Disease & Model & Observation & Ref. \\
\hline \multirow{2}{*}{ Mouse } & Ischemic brain damage & MCAO & Microarray analysis after RNAse R treatment & [90] \\
\cline { 2 - 5 } & TBI & Fluid percussion injury & RNA sequencing analysis from brain exosomes. & [93] \\
\hline \multirow{2}{*}{ Rat } & TBI & Fluid percussion injury & $\begin{array}{c}\text { Microarray analysis using RNA from ipsilateral } \\
\text { hippocampus after RNAse R treatment }\end{array}$ & [92] \\
\hline
\end{tabular}

MCAO: middle cerebral artery occlusion; PCR: Polymerase Chain Reaction; TBI: traumatic brain injury. 


\section{Future Directions and Conclusions}

The following points could be considered in future studies on the biomarker potential of non-coding RNAs after CA.

- Further deep RNA sequencing experiments are needed to identify the best candidates for prediction among the currently-identified 2500 human mature miRNAs, 146,000 human annotated lncRNAs and 32,000 predicted circRNAs.

- Independent validation of candidates in large patient cohorts will be the key to discovering robust and clinically-applicable biomarkers.

- Address gender specificities.

- Test the incremental predictive value of panels of non-coding RNAs using suitable correction strategies to avoid model overfitting.

- Assess the evolution of circulating levels of non-coding RNAs within the few hours/days after CA.

- Assess the influence of co-variates, such as age and target temperature, on circulating levels of non-coding RNAs.

- Define optimized protocols for blood sample collection, handling, storage and processing for RNA biomarkers assessment.

- Design molecular diagnostic assays for RNA assessment at the bedside that will allow clinically-applicable decision support systems combining biomarker assessment, neurophysiology, clinical examination, statistical analysis and risk stratification models.

Recent studies support the use of circulating miRNAs as predictors of outcome after CA. The potential of lncRNAs and circRNAs to aid in outcome prediction after CA needs to be further investigated. Using circulating, non-coding RNAs to risk stratify patients after CA would allow us to tailor healthcare to the individual patient, maximising efforts to those who would mostly benefit from aggressive therapy while avoiding therapeutic obstinacy in patients with poor prognoses. This would represent a major step forward towards precision medicine.

Author Contributions: A.S.-S., F.M.S. and Y.D. wrote the manuscript. P.S., H.F., D.E. and N.N. provided critical review and clinical guidance. All authors read and approved the final manuscript. All the authors are members of the Cardiolinc ${ }^{\mathrm{TM}}$ network (www.cardiolinc.org/).

Funding: This work was funded by the National Research Fund (grants \# C14/BM/8225223 and C17/BM/11613033), the Ministry of Higher Education and Research, the Society for Research on Cardiovascular Diseases of Luxembourg, the Swedish Research Council and the Swedish governmental funding within the ALF-system.

Acknowledgments: The authors thank A.I. Lumley for proof reading the manuscript.

Conflicts of Interest: The authors declare no conflict of interest.

\section{Abreviations}

$\begin{array}{ll}\text { CA } & \text { Cardiac arrest } \\ \text { circRNAs } & \text { Circular RNAs } \\ \text { HUVEC } & \text { Human umbilical vein endothelial cells } \\ \text { LAD } & \text { Left anterior descending } \\ \text { lncRNA } & \text { Long non-coding RNA } \\ \text { MCAO } & \text { Middle cerebral artery occlusion } \\ \text { miRNA } & \text { MicroRNA } \\ \text { NFkB } & \text { Nuclear Factor kappa B } \\ \text { NSE } & \text { Neuron Specific Enolase } \\ \text { OGD/R } & \text { Oxygen and glucose deprivation/reoxygenation } \\ \text { OHCA } & \text { Out-of-hospital cardiac arrest }\end{array}$




$\begin{array}{ll}\text { RNA } & \text { Ribonucleic acid } \\ \text { RNase } & \text { Ribonuclease } \\ \text { ROSC } & \text { Return Of Spontaneus Circulation } \\ \text { TBI } & \text { Traumatic brain injury } \\ \text { TNF } & \text { Tumor Necrosis Factor } \\ \text { TTM } & \text { Target Temperature Management }\end{array}$

\section{References}

1. Townsend, N.; Wilson, L.; Bhatnagar, P.; Wickramasinghe, K.; Rayner, M.; Nichols, M. Cardiovascular disease in Europe: Epidemiological update 2016. Eur. Heart J. 2016, 37, 3232-3245. [CrossRef] [PubMed]

2. Benjamin, E.J.; Blaha, M.J.; Chiuve, S.E.; Cushman, M.; Das, S.R.; Deo, R.; de Ferranti, S.D.; Floyd, J.; Fornage, M.; Gillespie, C.; et al. Heart Disease and Stroke Statistics-2017 Update: A Report From the American Heart Association. Circulation 2017, 135, e146-e603. [CrossRef] [PubMed]

3. Sandroni, C.; Nolan, J.; Cavallaro, F.; Antonelli, M. In-hospital cardiac arrest: Incidence, prognosis and possible measures to improve survival. Intens. Care Med. 2007, 33, 237-245. [CrossRef] [PubMed]

4. Wissenberg, M.; Lippert, F.K.; Folke, F.; Weeke, P.; Hansen, C.M.; Christensen, E.F.; Jans, H.; Hansen, P.A.; Lang-Jensen, T.; Olesen, J.B.; et al. Association of national initiatives to improve cardiac arrest management with rates of bystander intervention and patient survival after out-of-hospital cardiac arrest. JAMA 2013, 310, 1377-1384. [CrossRef] [PubMed]

5. Hasselqvist-Ax, I.; Riva, G.; Herlitz, J.; Rosenqvist, M.; Hollenberg, J.; Nordberg, P.; Ringh, M.; Jonsson, M.; Axelsson, C.; Lindqvist, J.; et al. Early cardiopulmonary resuscitation in out-of-hospital cardiac arrest. N. Engl. J. Med. 2015, 372, 2307-2315. [CrossRef] [PubMed]

6. Perkins, G.D.; Handley, A.J.; Koster, R.W.; Castren, M.; Smyth, M.A.; Olasveengen, T.; Monsieurs, K.G.; Raffay, V.; Grasner, J.T.; Wenzel, V.; et al. European Resuscitation Council Guidelines for Resuscitation 2015: Section 2. Adult basic life support and automated external defibrillation. Resuscitation 2015, 95, 81-99. [CrossRef] [PubMed]

7. Fordyce, C.B.; Hansen, C.M.; Kragholm, K.; Dupre, M.E.; Jollis, J.G.; Roettig, M.L.; Becker, L.B.; Hansen, S.M.; Hinohara, T.T.; Corbett, C.C.; et al. Association of Public Health Initiatives with Outcomes for Out-of-Hospital Cardiac Arrest at Home and in Public Locations. JAMA Cardiol. 2017, 2, 1226-1235. [CrossRef] [PubMed]

8. Larribau, R.; Deham, H.; Niquille, M.; Sarasin, F.P. Improvement of out-of-hospital cardiac arrest survival rate after implementation of the 2010 resuscitation guidelines. PLoS ONE 2018, 13, e0204169. [CrossRef] [PubMed]

9. Nielsen, N.; Wetterslev, J.; Cronberg, T.; Erlinge, D.; Gasche, Y.; Hassager, C.; Horn, J.; Hovdenes, J.; Kjaergaard, J.; Kuiper, M.; et al. Targeted temperature management at $33{ }^{\circ} \mathrm{C}$ versus $36{ }^{\circ} \mathrm{C}$ after cardiac arrest. N. Engl. J. Med. 2013, 369, 2197-2206. [CrossRef] [PubMed]

10. Moulaert, V.R.; Verbunt, J.A.; van Heugten, C.M.; Wade, D.T. Cognitive impairments in survivors of out-of-hospital cardiac arrest: A systematic review. Resuscitation 2009, 80, 297-305. [CrossRef] [PubMed]

11. Dragancea, I.; Horn, J.; Kuiper, M.; Friberg, H.; Ullen, S.; Wetterslev, J.; Cranshaw, J.; Hassager, C.; Nielsen, N.; Cronberg, T.; et al. Neurological prognostication after cardiac arrest and targeted temperature management $33{ }^{\circ} \mathrm{C}$ versus $36^{\circ} \mathrm{C}$ : Results from a randomised controlled clinical trial. Resuscitation 2015, 93, 164-170. [CrossRef] [PubMed]

12. Winther-Jensen, M.; Pellis, T.; Kuiper, M.; Koopmans, M.; Hassager, C.; Nielsen, N.; Wetterslev, J.; Cronberg, T.; Erlinge, D.; Friberg, H.; et al. Mortality and neurological outcome in the elderly after target temperature management for out-of-hospital cardiac arrest. Resuscitation 2015, 91, 92-98. [CrossRef] [PubMed]

13. Karlsson, V.; Dankiewicz, J.; Nielsen, N.; Kern, K.B.; Mooney, M.R.; Riker, R.R.; Rubertsson, S.; Seder, D.B.; Stammet, P.; Sunde, K.; et al. Association of gender to outcome after out-of-hospital cardiac arrest-A report from the International Cardiac Arrest Registry. Crit. Care 2015, 19, 182. [CrossRef] [PubMed]

14. Gupta, T.; Kolte, D.; Khera, S.; Aronow, W.S.; Palaniswamy, C.; Mujib, M.; Jain, D.; Sule, S.; Ahmed, A.; Iwai, S.; et al. Relation of smoking status to outcomes after cardiopulmonary resuscitation for in-hospital cardiac arrest. Am. J. Cardiol. 2014, 114, 169-174. [CrossRef] [PubMed] 
15. Gupta, T.; Kolte, D.; Mohananey, D.; Khera, S.; Goel, K.; Mondal, P.; Aronow, W.S.; Jain, D.; Cooper, H.A.; Iwai, S.; et al. Relation of Obesity to Survival After In-Hospital Cardiac Arrest. Am. J. Cardiol. 2016, 118, 662-667. [CrossRef] [PubMed]

16. Matinrazm, S.; Ladejobi, A.; Pasupula, D.K.; Javed, A.; Durrani, A.; Ahmad, S.; Munir, M.B.; Adelstein, E.; Jain, S.K.; Saba, S. Effect of body mass index on survival after sudden cardiac arrest. Clin. Cardiol. 2018, 41, 46-50. [CrossRef] [PubMed]

17. Stammet, P.; Collignon, O.; Hassager, C.; Wise, M.P.; Hovdenes, J.; Aneman, A.; Horn, J.; Devaux, Y.; Erlinge, D.; Kjaergaard, J.; et al. Neuron-Specific Enolase as a Predictor of Death or Poor Neurological Outcome After Out-of-Hospital Cardiac Arrest and Targeted Temperature Management at $33^{\circ} \mathrm{C}$ and $36{ }^{\circ} \mathrm{C}$. J. Am. Coll. Cardiol. 2015, 65, 2104-2114. [CrossRef] [PubMed]

18. Devaux, Y.; Stammet, P.; Friberg, H.; Hassager, C.; Kuiper, M.A.; Wise, M.P.; Nielsen, N.; Biomarker subcommittee of TTM trial (Target Temperature Management After Cardiac Arrest, NCT01020916). MicroRNAs: New biomarkers and therapeutic targets after cardiac arrest? Crit. Care 2015, 19, 54. [CrossRef] [PubMed]

19. Deakin, C.D.; Nolan, J.P.; Soar, J.; Sunde, K.; Koster, R.W.; Smith, G.B.; Perkins, G.D. European Resuscitation Council Guidelines for Resuscitation 2010 Section 4. Adult advanced life support. Resuscitation 2010, 81, 1305-1352. [CrossRef] [PubMed]

20. Nolan, J.P.; Soar, J.; Cariou, A.; Cronberg, T.; Moulaert, V.R.; Deakin, C.D.; Bottiger, B.W.; Friberg, H.; Sunde, K.; Sandroni, C.; et al. European Resuscitation Council and European Society of Intensive Care Medicine 2015 guidelines for post-resuscitation care. Intens. Care Med. 2015, 41, 2039-2056. [CrossRef] [PubMed]

21. Zandbergen, E.G.; Hijdra, A.; Koelman, J.H.; Hart, A.A.; Vos, P.E.; Verbeek, M.M.; de Haan, R.J.; Group, P.S. Prediction of poor outcome within the first 3 days of postanoxic coma. Neurology 2006, 66, 62-68. [CrossRef] [PubMed]

22. Nolan, J.P.; Soar, J.; Cariou, A.; Cronberg, T.; Moulaert, V.R.; Deakin, C.D.; Bottiger, B.W.; Friberg, H.; Sunde, K.; Sandroni, C. European Resuscitation Council and European Society of Intensive Care Medicine Guidelines for Post-resuscitation Care 2015: Section 5 of the European Resuscitation Council Guidelines for Resuscitation 2015. Resuscitation 2015, 95, 202-222. [CrossRef] [PubMed]

23. Storm, C.; Nee, J.; Jorres, A.; Leithner, C.; Hasper, D.; Ploner, C.J. Serial measurement of neuron specific enolase improves prognostication in cardiac arrest patients treated with hypothermia: A prospective study. Scand. J. Trauma Resusc. Emerg. Med. 2012, 20, 6. [CrossRef] [PubMed]

24. Schoerkhuber, W.; Kittler, H.; Sterz, F.; Behringer, W.; Holzer, M.; Frossard, M.; Spitzauer, S.; Laggner, A.N. Time course of serum neuron-specific enolase. A predictor of neurological outcome in patients resuscitated from cardiac arrest. Stroke 1999, 30, 1598-1603. [CrossRef] [PubMed]

25. Rech, T.H.; Vieira, S.R.; Nagel, F.; Brauner, J.S.; Scalco, R. Serum neuron-specific enolase as early predictor of outcome after in-hospital cardiac arrest: A cohort study. Crit. Care 2006, 10, R133. [CrossRef] [PubMed]

26. Rundgren, M.; Karlsson, T.; Nielsen, N.; Cronberg, T.; Johnsson, P.; Friberg, H. Neuron specific enolase and S-100B as predictors of outcome after cardiac arrest and induced hypothermia. Resuscitation 2009, 80, 784-789. [CrossRef] [PubMed]

27. Burghuber, O.C.; Worofka, B.; Schernthaner, G.; Vetter, N.; Neumann, M.; Dudczak, R.; Kuzmits, R. Serum neuron-specific enolase is a useful tumor marker for small cell lung cancer. Cancer 1990, 65, 1386-1390. [CrossRef]

28. DeGiorgio, C.M.; Gott, P.S.; Rabinowicz, A.L.; Heck, C.N.; Smith, T.D.; Correale, J.D. Neuron-specific enolase, a marker of acute neuronal injury, is increased in complex partial status epilepticus. Epilepsia 1996, 37, 606-609. [CrossRef] [PubMed]

29. Pelinka, L.E.; Jafarmadar, M.; Redl, H.; Bahrami, S. Neuron-specific-enolase is increased in plasma after hemorrhagic shock and after bilateral femur fracture without traumatic brain injury in the rat. Shock 2004, 22, 88-91. [CrossRef] [PubMed]

30. Choi, S.; Park, K.; Ryu, S.; Kang, T.; Kim, H.; Cho, S.; Oh, S. Use of S-100B, NSE, CRP and ESR to predict neurological outcomes in patients with return of spontaneous circulation and treated with hypothermia. Emerg. Med. J. 2016, 33, 690-695. [CrossRef] [PubMed] 
31. Mussack, T.; Biberthaler, P.; Kanz, K.G.; Wiedemann, E.; Gippner-Steppert, C.; Mutschler, W.; Jochum, M. Serum S-100B and interleukin-8 as predictive markers for comparative neurologic outcome analysis of patients after cardiac arrest and severe traumatic brain injury. Crit. Care Med. 2002, 30, 2669-2674. [CrossRef] [PubMed]

32. Randall, J.; Mortberg, E.; Provuncher, G.K.; Fournier, D.R.; Duffy, D.C.; Rubertsson, S.; Blennow, K.; Zetterberg, H.; Wilson, D.H. Tau proteins in serum predict neurological outcome after hypoxic brain injury from cardiac arrest: Results of a pilot study. Resuscitation 2013, 84, 351-356. [CrossRef] [PubMed]

33. Mortberg, E.; Zetterberg, H.; Nordmark, J.; Blennow, K.; Catry, C.; Decraemer, H.; Vanmechelen, E.; Rubertsson, S. Plasma tau protein in comatose patients after cardiac arrest treated with therapeutic hypothermia. Acta Anaesthesiol. Scand. 2011, 55, 1132-1138. [CrossRef] [PubMed]

34. Rana, O.R.; Schroder, J.W.; Baukloh, J.K.; Saygili, E.; Mischke, K.; Schiefer, J.; Weis, J.; Marx, N.; Rassaf, T.; Kelm, M.; et al. Neurofilament light chain as an early and sensitive predictor of long-term neurological outcome in patients after cardiac arrest. Int. J. Cardiol. 2013, 168, 1322-1327. [CrossRef] [PubMed]

35. Fries, M.; Kunz, D.; Gressner, A.M.; Rossaint, R.; Kuhlen, R. Procalcitonin serum levels after out-of-hospital cardiac arrest. Resuscitation 2003, 59, 105-109. [CrossRef]

36. Stammet, P.; Devaux, Y.; Azuaje, F.; Werer, C.; Lorang, C.; Gilson, G.; Max, M. Assessment of procalcitonin to predict outcome in hypothermia-treated patients after cardiac arrest. Crit. Care Res. Pract. 2011, 2011, 631062. [CrossRef] [PubMed]

37. Hayashida, H.; Kaneko, T.; Kasaoka, S.; Oshima, C.; Miyauchi, T.; Fujita, M.; Oda, Y.; Tsuruta, R.; Maekawa, T. Comparison of the predictability of neurological outcome by serum procalcitonin and glial fibrillary acidic protein in postcardiac-arrest patients. Neurocrit. Care 2010, 12, 252-257. [CrossRef] [PubMed]

38. Assicot, M.; Gendrel, D.; Carsin, H.; Raymond, J.; Guilbaud, J.; Bohuon, C. High serum procalcitonin concentrations in patients with sepsis and infection. Lancet 1993, 341, 515-518. [CrossRef]

39. Wiberg, S.; Hassager, C.; Stammet, P.; Winther-Jensen, M.; Thomsen, J.H.; Erlinge, D.; Wanscher, M.; Nielsen, N.; Pellis, T.; Aneman, A.; et al. Single versus Serial Measurements of Neuron-Specific Enolase and Prediction of Poor Neurological Outcome in Persistently Unconscious Patients after Out-Of-Hospital Cardiac Arrest-A TTM-Trial Substudy. PLoS ONE 2017, 12, e0168894. [CrossRef] [PubMed]

40. Sandroni, C.; Cariou, A.; Cavallaro, F.; Cronberg, T.; Friberg, H.; Hoedemaekers, C.; Horn, J.; Nolan, J.P.; Rossetti, A.O.; Soar, J. Prognostication in comatose survivors of cardiac arrest: An advisory statement from the European Resuscitation Council and the European Society of Intensive Care Medicine. Resuscitation 2014, 85, 1779-1789. [CrossRef] [PubMed]

41. Chung-Esaki, H.M.; Mui, G.; Mlynash, M.; Eyngorn, I.; Catabay, K.; Hirsch, K.G. The neuron specific enolase (NSE) ratio offers benefits over absolute value thresholds in post-cardiac arrest coma prognosis. J. Clin. Neurosci. 2018, 57, 99-104. [CrossRef] [PubMed]

42. Stammet, P.; Wagner, D.R.; Gilson, G.; Devaux, Y. Modeling serum level of s100beta and bispectral index to predict outcome after cardiac arrest. J. Am. Coll. Cardiol. 2013, 62, 851-858. [CrossRef] [PubMed]

43. Stammet, P.; Dankiewicz, J.; Nielsen, N.; Fays, F.; Collignon, O.; Hassager, C.; Wanscher, M.; Unden, J.; Wetterslev, J.; Pellis, T.; et al. Protein S100 as outcome predictor after out-of-hospital cardiac arrest and targeted temperature management at $33^{\circ} \mathrm{C}$ and $36^{\circ} \mathrm{C}$. Crit. Care 2017, 21, 153. [CrossRef] [PubMed]

44. Jonsson, H.; Johnsson, P.; Hoglund, P.; Alling, C.; Blomquist, S. Elimination of S100B and renal function after cardiac surgery. J. Cardiothorac. Vasc. Anesth. 2000, 14, 698-701. [CrossRef] [PubMed]

45. Bloomfield, S.M.; McKinney, J.; Smith, L.; Brisman, J. Reliability of S100B in predicting severity of central nervous system injury. Neurocrit. Care 2007, 6, 121-138. [CrossRef] [PubMed]

46. Bro-Jeppesen, J.; Kjaergaard, J.; Stammet, P.; Wise, M.P.; Hovdenes, J.; Aneman, A.; Horn, J.; Devaux, Y.; Erlinge, D.; Gasche, Y.; et al. Predictive value of interleukin-6 in post-cardiac arrest patients treated with targeted temperature management at $33^{\circ} \mathrm{C}$ or $36{ }^{\circ} \mathrm{C}$. Resuscitation 2016, 98, 1-8. [CrossRef] [PubMed]

47. Dankiewicz, J.; Nielsen, N.; Linder, A.; Kuiper, M.; Wise, M.P.; Cronberg, T.; Erlinge, D.; Gasche, Y.; Harmon, M.B.; Hassager, C.; et al. Infectious complications after out-of-hospital cardiac arrest-A comparison between two target temperatures. Resuscitation 2017, 113, 70-76. [CrossRef] [PubMed]

48. Frydland, M.; Kjaergaard, J.; Erlinge, D.; Stammet, P.; Nielsen, N.; Wanscher, M.; Pellis, T.; Friberg, H.; Hovdenes, J.; Horn, J.; et al. Usefulness of Serum B-Type Natriuretic Peptide Levels in Comatose Patients Resuscitated from Out-of-Hospital Cardiac Arrest to Predict Outcome. Am. J. Cardiol. 2016, 118, 998-1005. [CrossRef] [PubMed] 
49. Gilje, P.; Koul, S.; Thomsen, J.H.; Devaux, Y.; Friberg, H.; Kuiper, M.; Horn, J.; Nielsen, N.; Pellis, T.; Stammet, P.; et al. High-sensitivity troponin-T as a prognostic marker after out-of-hospital cardiac arrest-A targeted temperature management (TTM) trial substudy. Resuscitation 2016, 107, 156-161. [CrossRef] [PubMed]

50. Frydland, M.; Kjaergaard, J.; Erlinge, D.; Wanscher, M.; Nielsen, N.; Pellis, T.; Aneman, A.; Friberg, H.; Hovdenes, J.; Horn, J.; et al. Target temperature management of $33{ }^{\circ} \mathrm{C}$ and $36{ }^{\circ} \mathrm{C}$ in patients with out-of-hospital cardiac arrest with initial non-shockable rhythm-A TTM sub-study. Resuscitation 2015, 89, 142-148. [CrossRef] [PubMed]

51. Hasslacher, J.; Lehner, G.F.; Harler, U.; Beer, R.; Ulmer, H.; Kirchmair, R.; Fischer-Colbrie, R.; Bellmann, R.; Dunzendorfer, S.; Joannidis, M. Secretoneurin as a marker for hypoxic brain injury after cardiopulmonary resuscitation. Intens. Care Med. 2014, 40, 1518-1527. [CrossRef] [PubMed]

52. Consortium, E.P. An integrated encyclopedia of DNA elements in the human genome. Nature 2012, 489, 57-74. [CrossRef] [PubMed]

53. Goretti, E.; Wagner, D.R.; Devaux, Y. miRNAs as biomarkers of myocardial infarction: A step forward towards personalized medicine? Trends Mol. Med. 2014, 20, 716-725. [CrossRef] [PubMed]

54. Stammet, P.; Goretti, E.; Vausort, M.; Zhang, L.; Wagner, D.R.; Devaux, Y. Circulating microRNAs after cardiac arrest. Crit. Care Med. 2012, 40, 3209-3214. [CrossRef] [PubMed]

55. Lei, P.; Li, Y.; Chen, X.; Yang, S.; Zhang, J. Microarray based analysis of microRNA expression in rat cerebral cortex after traumatic brain injury. Brain Res. 2009, 1284, 191-201. [CrossRef] [PubMed]

56. Andersson, P.; Gidlof, O.; Braun, O.O.; Gotberg, M.; van der Pals, J.; Olde, B.; Erlinge, D. Plasma levels of liver-specific miR-122 is massively increased in a porcine cardiogenic shock model and attenuated by hypothermia. Shock 2012, 37, 234-238. [CrossRef] [PubMed]

57. Wander, P.L.; Enquobahrie, D.A.; Pritchard, C.C.; McKnight, B.; Rice, K.; Christiansen, M.; Lemaitre, R.N.; Rea, T.; Siscovick, D.; Sotoodehnia, N. Circulating microRNAs and sudden cardiac arrest outcomes. Resuscitation 2016, 106, 96-101. [CrossRef] [PubMed]

58. Braza-Boils, A.; Mari-Alexandre, J.; Molina, P.; Arnau, M.A.; Barcelo-Molina, M.; Domingo, D.; Girbes, J.; Giner, J.; Martinez-Dolz, L.; Zorio, E. Deregulated hepatic microRNAs underlie the association between non-alcoholic fatty liver disease and coronary artery disease. Liver Int. 2016, 36, 1221-1229. [CrossRef] [PubMed]

59. Gilje, P.; Gidlof, O.; Rundgren, M.; Cronberg, T.; Al-Mashat, M.; Olde, B.; Friberg, H.; Erlinge, D. The brain-enriched microRNA miR-124 in plasma predicts neurological outcome after cardiac arrest. Crit. Care 2014, 18, R40. [CrossRef] [PubMed]

60. Laterza, O.F.; Lim, L.; Garrett-Engele, P.W.; Vlasakova, K.; Muniappa, N.; Tanaka, W.K.; Johnson, J.M.; Sina, J.F.; Fare, T.L.; Sistare, F.D.; et al. Plasma MicroRNAs as sensitive and specific biomarkers of tissue injury. Clin. Chem. 2009, 55, 1977-1983. [CrossRef] [PubMed]

61. Patz, S.; Trattnig, C.; Grunbacher, G.; Ebner, B.; Gully, C.; Novak, A.; Rinner, B.; Leitinger, G.; Absenger, M.; Tomescu, O.A.; et al. More than cell dust: Microparticles isolated from cerebrospinal fluid of brain injured patients are messengers carrying mRNAs, miRNAs, and proteins. J. Neurotrauma 2013, 30, 1232-1242. [CrossRef] [PubMed]

62. Weng, H.; Shen, C.; Hirokawa, G.; Ji, X.; Takahashi, R.; Shimada, K.; Kishimoto, C.; Iwai, N. Plasma miR-124 as a biomarker for cerebral infarction. Biomed. Res. 2011, 32, 135-141. [CrossRef] [PubMed]

63. Rink, C.; Khanna, S. MicroRNA in ischemic stroke etiology and pathology. Physiol. Genom. 2011, 43, 521-528. [CrossRef] [PubMed]

64. Devaux, Y.; Dankiewicz, J.; Salgado-Somoza, A.; Stammet, P.; Collignon, O.; Gilje, P.; Gidlof, O.; Zhang, L.; Vausort, M.; Hassager, C.; et al. Association of Circulating MicroRNA-124-3p Levels With Outcomes After Out-of-Hospital Cardiac Arrest: A Substudy of a Randomized Clinical Trial. JAMA Cardiol. 2016, 1, 305-313. [CrossRef] [PubMed]

65. Devaux, Y.; Salgado-Somoza, A.; Dankiewicz, J.; Boileau, A.; Stammet, P.; Schritz, A.; Zhang, L.; Vausort, M.; Gilje, P.; Erlinge, D.; et al. Incremental Value of Circulating MiR-122-5p to Predict Outcome after Out of Hospital Cardiac Arrest. Theranostics 2017, 7, 2555-2564. [CrossRef] [PubMed]

66. Yu, Y.; Cao, F.; Ran, Q.; Wang, F. Long non-coding RNA Gm4419 promotes trauma-induced astrocyte apoptosis by targeting tumor necrosis factor alpha. Biochem. Biophys. Res. Commun. 2017, 491, 478-485. [CrossRef] [PubMed] 
67. Mercer, T.R.; Dinger, M.E.; Mattick, J.S. Long non-coding RNAs: Insights into functions. Nat. Rev. Genet. 2009, 10, 155-159. [CrossRef] [PubMed]

68. Ponting, C.P.; Oliver, P.L.; Reik, W. Evolution and functions of long noncoding RNAs. Cell 2009, 136, 629-641. [CrossRef] [PubMed]

69. Volders, P.J.; Verheggen, K.; Menschaert, G.; Vandepoele, K.; Martens, L.; Vandesompele, J.; Mestdagh, P. An update on LNCipedia: A database for annotated human lncRNA sequences. Nucleic Acids Res. 2015, 43, D174-D180. [CrossRef] [PubMed]

70. Devaux, Y.; Zangrando, J.; Schroen, B.; Creemers, E.E.; Pedrazzini, T.; Chang, C.P.; Dorn, G.W., 2nd; Thum, T.; Heymans, S.; Cardiolinc, N. Long noncoding RNAs in cardiac development and ageing. Nat. Rev. Cardiol. 2015, 12, 415-425. [CrossRef] [PubMed]

71. Beermann, J.; Piccoli, M.T.; Viereck, J.; Thum, T. Non-coding RNAs in Development and Disease: Background, Mechanisms, and Therapeutic Approaches. Physiol. Rev. 2016, 96, 1297-1325. [CrossRef] [PubMed]

72. Gomes, C.P.C.; Spencer, H.; Ford, K.L.; Michel, L.Y.M.; Baker, A.H.; Emanueli, C.; Balligand, J.L.; Devaux, Y.; Cardiolinc, N. The Function and Therapeutic Potential of Long Non-coding RNAs in Cardiovascular Development and Disease. Mol. Therapy Nucleic Acids 2017, 8, 494-507. [CrossRef] [PubMed]

73. Greco, S.; Salgado Somoza, A.; Devaux, Y.; Martelli, F. Long Noncoding RNAs and Cardiac Disease. Antioxid. Redox Signal. 2017. [CrossRef] [PubMed]

74. Vausort, M.; Wagner, D.R.; Devaux, Y. Long noncoding RNAs in patients with acute myocardial infarction. Circul. Res. 2014, 115, 668-677. [CrossRef] [PubMed]

75. Chen, Y.; Zhou, J. LncRNAs: Macromolecules with big roles in neurobiology and neurological diseases. Metab. Brain Dis. 2017, 32, 281-291. [CrossRef] [PubMed]

76. Liu, J.; Li, Q.; Zhang, K.S.; Hu, B.; Niu, X.; Zhou, S.M.; Li, S.G.; Luo, Y.P.; Wang, Y.; Deng, Z.F. Downregulation of the Long Non-Coding RNA Meg3 Promotes Angiogenesis After Ischemic Brain Injury by Activating Notch Signaling. Mol. Neurobiol. 2017, 54, 8179-8190. [CrossRef] [PubMed]

77. Mehta, S.L.; Kim, T.; Vemuganti, R. Long Noncoding RNA FosDT Promotes Ischemic Brain Injury by Interacting with REST-Associated Chromatin-Modifying Proteins. J. Neurosci. 2015, 35, 16443-16449. [CrossRef] [PubMed]

78. Xu, Q.; Deng, F.; Xing, Z.; Wu, Z.; Cen, B.; Xu, S.; Zhao, Z.; Nepomuceno, R.; Bhuiyan, M.I.; Sun, D.; et al. Long non-coding RNA C2dat1 regulates CaMKIIdelta expression to promote neuronal survival through the NFkB signaling pathway following cerebral ischemia. Cell Death Dis. 2016, 7, e2173. [CrossRef] [PubMed]

79. Wen, Y.; Yu, Y.; Fu, X. LncRNA Gm4419 contributes to OGD/R injury of cerebral microglial cells via IкB phosphorylation and NFkB activation. Biochem. Biophys. Res. Commun. 2017, 487, 923-929. [CrossRef] [PubMed]

80. Liu, R.; Liao, X.; Li, X.; Wei, H.; Liang, Q.; Zhang, Z.; Yin, M.; Zeng, X.; Liang, Z.; Hu, C. Expression profiles of long noncoding RNAs and mRNAs in post-cardiac arrest rat brains. Mol. Med. Rep. 2018, 17, 6413-6424. [CrossRef] [PubMed]

81. Zhong, J.; Jiang, L.; Huang, Z.; Zhang, H.; Cheng, C.; Liu, H.; He, J.; Wu, J.; Darwazeh, R.; Wu, Y.; et al. The long non-coding RNA Neat1 is an important mediator of the therapeutic effect of bexarotene on traumatic brain injury in mice. Brain Behav. Immun. 2017, 65, 183-194. [CrossRef] [PubMed]

82. Zhong, J.; Jiang, L.; Cheng, C.; Huang, Z.; Zhang, H.; Liu, H.; He, J.; Cao, F.; Peng, J.; Jiang, Y.; et al. Altered expression of long non-coding RNA and mRNA in mouse cortex after traumatic brain injury. Brain Res. 2016, 1646, 589-600. [CrossRef] [PubMed]

83. Wang, C.F.; Zhao, C.C.; Weng, W.J.; Lei, J.; Lin, Y.; Mao, Q.; Gao, G.Y.; Feng, J.F.; Jiang, J.Y. Alteration in Long Non-Coding RNA Expression after Traumatic Brain Injury in Rats. J. Neurotrauma 2017, 34, 2100-2108. [CrossRef] [PubMed]

84. Zheng, B.; Liu, H.; Wang, R.; Xu, S.; Liu, Y.; Wang, K.; Hou, X.; Shen, C.; Wu, J.; Chen, X.; et al. Expression signatures of long non-coding RNAs in early brain injury following experimental subarachnoid hemorrhage. Mol. Med. Rep. 2015, 12, 967-973. [CrossRef] [PubMed]

85. Peng, J.; Wu, Y.; Tian, X.; Pang, J.; Kuai, L.; Cao, F.; Qin, X.; Zhong, J.; Li, X.; Li, Y.; et al. High-Throughput Sequencing and Co-Expression Network Analysis of lncRNAs and mRNAs in Early Brain Injury Following Experimental Subarachnoid Haemorrhage. Sci. Rep. 2017, 7, 46577. [CrossRef] [PubMed] 
86. Memczak, S.; Papavasileiou, P.; Peters, O.; Rajewsky, N. Identification and Characterization of Circular RNAs As a New Class of Putative Biomarkers in Human Blood. PLoS ONE 2015, 10, e0141214. [CrossRef] [PubMed]

87. Devaux, Y.; Creemers, E.E.; Boon, R.A.; Werfel, S.; Thum, T.; Engelhardt, S.; Dimmeler, S.; Squire, I.; Cardiolinc, n. Circular RNAs in heart failure. Eur. J. Heart Fail. 2017, 19, 701-709. [CrossRef] [PubMed]

88. Suzuki, H.; Zuo, Y.; Wang, J.; Zhang, M.Q.; Malhotra, A.; Mayeda, A. Characterization of RNase R-digested cellular RNA source that consists of lariat and circular RNAs from pre-mRNA splicing. Nucleic Acids Res. 2006, 34, e63. [CrossRef] [PubMed]

89. Vausort, M.; Salgado-Somoza, A.; Zhang, L.; Leszek, P.; Scholz, M.; Teren, A.; Burkhardt, R.; Thiery, J.; Wagner, D.R.; Devaux, Y. Myocardial Infarction-Associated Circular RNA Predicting Left Ventricular Dysfunction. J. Am. Coll. Cardiol. 2016, 68, 1247-1248. [CrossRef] [PubMed]

90. Liu, C.; Zhang, C.; Yang, J.; Geng, X.; Du, H.; Ji, X.; Zhao, H. Screening circular RNA expression patterns following focal cerebral ischemia in mice. Oncotarget 2017, 8, 86535-86547. [CrossRef] [PubMed]

91. Mehta, S.L.; Pandi, G.; Vemuganti, R. Circular RNA Expression Profiles Alter Significantly in Mouse Brain After Transient Focal Ischemia. Stroke 2017, 48, 2541-2548. [CrossRef] [PubMed]

92. Xie, B.; Wang, Y.; Lin, Y.; Zhao, C.C.; Mao, Q.; Feng, J.F.; Cao, J.; Gao, G.Y.; Jiang, J. Circular RNA Expression Profiles Alter Significantly After Traumatic Brain Injury in Rats. J. Neurotrauma 2018. [CrossRef] [PubMed]

93. Zhao, R.; Zhou, J.; Dong, X.; Bi, C.; Jiang, R.; Dong, J.; Tian, Y.; Yuan, H.; Zhang, J.N. Circular RNA expression alteration in exosomes from the brain extracellular space after traumatic brain injury in mice. J. Neurotrauma 2018. [CrossRef] [PubMed]

(c) 2018 by the authors. Licensee MDPI, Basel, Switzerland. This article is an open access article distributed under the terms and conditions of the Creative Commons Attribution (CC BY) license (http://creativecommons.org/licenses/by/4.0/). 